\title{
STRENTHENING OF SHORT REINFORCEMENT CONCRETE CORBEL USING STEEL ACCESSORY
}

\author{
T. URBAN ${ }^{1}$, L. KRAWCZYK², M. GOLDYN ${ }^{3}$
}

\begin{abstract}
In the paper experimental investigation results of three elements are presented. Two of them were made of reinforced concrete. The strengthened bracket had the steel accessory mounted to cracked loaded corbel (while it was loaded to half ultimate force of the reference element), the reference one was tested without any accessory. The third corbel was the steel accessory mounted to the concrete column. Full scale corbels were $450 \mathrm{~mm}$ deep and $250 \mathrm{~mm}$ wide, steel accessory was $320 \mathrm{~mm}$ high. The aim of the research was to verify the following thesis: short corbels (shear slenderness $a_{c} / h \approx 0,3$ ) can be strengthened by a steel accessory. Load carrying capacity of strengthened member increased by $40 \%$. The ultimate force obtained for the steel accessories mounted to concrete column was $66 \%$ of reference value. While testing some observations and measurements (strain of reinforcement and concrete, development of cracking) were made which allowed to describe corbel behaviour under increasing load.
\end{abstract}

Keywords: corbels, strengthening, steel accessory, post-installed rods, Embedded Through-Section technique

\section{INTRODUCTION}

The strengthening of existing building structures is a current issue and many research centres around the world are interested in this topic. This paper applies to corbels so the general issue connected with strengthening of structures are not discussed.

\footnotetext{
${ }^{1}$ DSc., PhD., Eng., Lodz University of Technology, Faculty of Civil Engineering, Al. Politechniki 6, 90-924 Lodz, Poland, e-mail: tadeusz.urban@p.lodz.pl

${ }^{2}$ PhD., Eng., Lodz University of Technology, Faculty of Civil Engineering, Al. Politechniki 6, 90-924 Lodz,, Poland, e-mail: lukasz.krawczyk@p.lodz.pl

${ }^{3}$ PhD., Eng., Lodz University of Technology, Faculty of Civil Engineering, Al. Politechniki 6, 90-924 Lodz,, Poland, e-mail: michal.goldyn@p.lodz.pl
} 
The most common method of strengthening corbels is installing additional external reinforcement. Extensive experimental investigation in this field were made by Nagrodzka - Godycka [1-4]. Some parameters were checked, the most important was the influence of using active or passive rods. The additional rods were installed at a level of main reinforcement. For elements with the shear slenderness $\left(a_{d} / d\right)$ equal of 0,3 and 0,6 the increase in the ultimate force reached $11 \%$. Load carrying capacity of corbel with $a_{c} / d=1$ strengthened by active rods was $40 \%$ higher than for the reference (unstrengthened) element. Due to the low efficiency of the presented method with reference to very short corbels modification of strengthening was proposed. NagrodzkaGodycka [3] presented the results of experimental investigation of corbels $\left(a_{c} / d=0,3\right)$ with active rods in the middle of an element height. The increase in the ultimate forces was $30 \% \div 40 \%$ with reference to the unstrengthened element. The influence of a parameter called softening coefficient (the value connected with change of compressive strength of laterally tensioned concrete) is discussed in theoretical analysis shown in [3].

Recently many papers connected with strengthening of corbels using CFRP sheets or plates have been published. Some examples can be quoted: Corry and Dolan [5], Campione at all. [6], Elgwady at all. [7], Ahmad at all.[8], El-Maaddawy and Sherif [9], Ivanova [10]. Based on these papers it can be stated that the process of failure corbels strengthened using CFRP is very brittle and unexpected. Ultimate load is limited by bond of sheets or plates to concrete - debonding is typical kind of failure. Well described and complex investigation [10] showed that using two CFRP plates on corbel with low main reinforcement ratio $\rho_{l} \approx 0,3 \%$ caused increase of ultimate load up to $55 \%$. Using three layers of plates instead of two gave much less ultimate force (instead of $55 \%$ only $6 \%$ increase of ultimate force was obtained). A similar effect was observed for corbels strengthened by CFRP sheets.

The other type of strengthening technique is Embedded Through Section (ETS). This method was used by Urban [11-13] and Breveglieri at all. [14-17] in order to strengthen RC beams in shear. Muttoni at all $[18,19]$ used ETS (post-installed) rods to increase ultimate force both for beams in shear and flat slabs in punching shear. The results of these investigations showed high efficiency and led to testing corbels similarly strengthened. That method of strengthening was described by Urban at all. [20,21] and in the $\mathrm{PhD}$ thesis by Krawczyk [21].

Strengthening of corbels using steel accessory fixed by ETS rods was presented in [22] where the element with shear slenderness $a_{c} / d=0,6$ was used. The calculating idea of this element was presented by Krawczyk and Urban in [23]. In Figure 1 the corbel described in paper [22] is showed. 


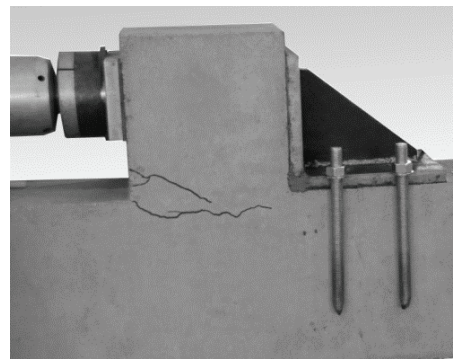

a)

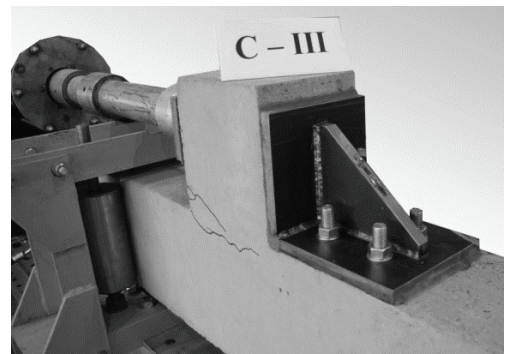

b)

Fig. 1. Rods anchoring accessory to column: a) view of rods before embedding b) corbel after strengthening

The investigation proved high effectiveness of the proposed method for corbels. In the quoted paper [22] the strengthened element did not fail because of the hydraulic jack limit. The maximum force obtained in the strengthened element was $150 \%$ higher than in the reference corbel. The next step was to remove reinforced concrete and to test the steel accessory only. The authors believe that the presented method is fast and easy to apply. Moreover, in this type of technique a drilling in the corbel is not needed, but embedding rods in the column is necessary to strengthen the element. Bond of the rods to concrete using mortar was very effective. Failure of rods was connected with concrete cone failure (see Fig. 2)

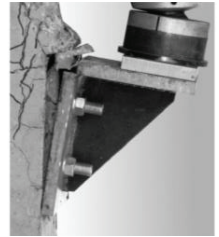

a)

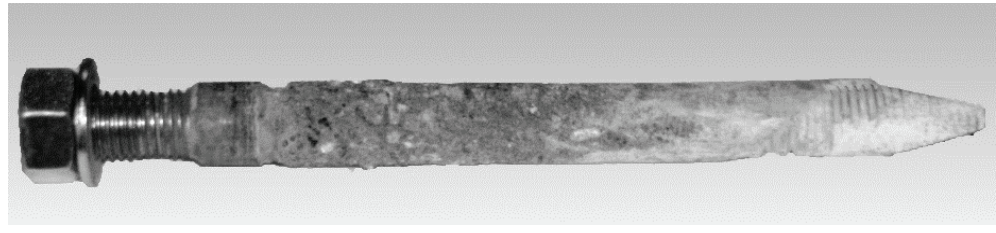

b)

Fig. 2. Testing element after failure a) view b) rod surrounded by mortar.

\section{EXPERIMENTAL PROGRAM OF VERY SHORT CORBELS}

It is well known that the shear slenderness strongly influences the behaviour and ultimate load of corbels. According to EN-1992-1-1 [24] the strut and tie method can be applied in elements for which the inclination of the strut is limited by $1,0 \leq \tan \theta \leq 2,5$ (for newly designed corbels). According to the authors the same limitation should be used to Embedded Through Section rods because they behave similarly to a typical reinforcement of elements [22]. Corbels with the strut 
inclination higher than $68,2^{\circ}$ and low reinforcement ratio calculated using strut and tie method give very conservative results. Moreover, it is more difficult to obtain strengthening using additional rods in short corbels than for elements with higher shear slenderness.

In the paper experiment investigation connected with strengthening of corbels with shear slenderness $a_{c} / h \approx 0,3$ using steel accessories mounted by Embedded Through Section steel rods to column is presented. Three elements were prepared. Two of them were made of reinforced concrete, its dimensions were: height $-450 \mathrm{~mm}$, width $-250 \mathrm{~mm}$. The main reinforcement was made of three bars with diameter equal $16 \mathrm{~mm}$, ratio of reinforcement was $\rho \mathrm{l} \approx 0,6 \%$. The stirrups were made of $8 \mathrm{~mm}$ diameter bars. The strengthened bracket ( $\mathrm{F}-\mathrm{I}$ ) was loaded to about half ultimate force of the reference one $(\mathrm{F}-0)$ and strengthened while the load was being applied. The reference corbel was tested without any accessory. The third corbel (F - II) was the steel accessory mounted to the concrete column. The steel accessories in both F - I and F - II were mounted by ETS threaten rods, diameter $20 \mathrm{~mm}$ (M20). In Figure 3 and 4 details of the elements are presented.

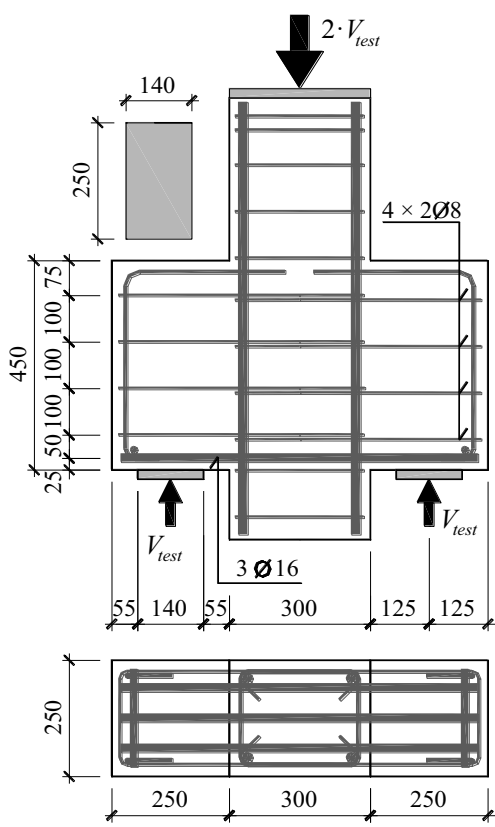

a)
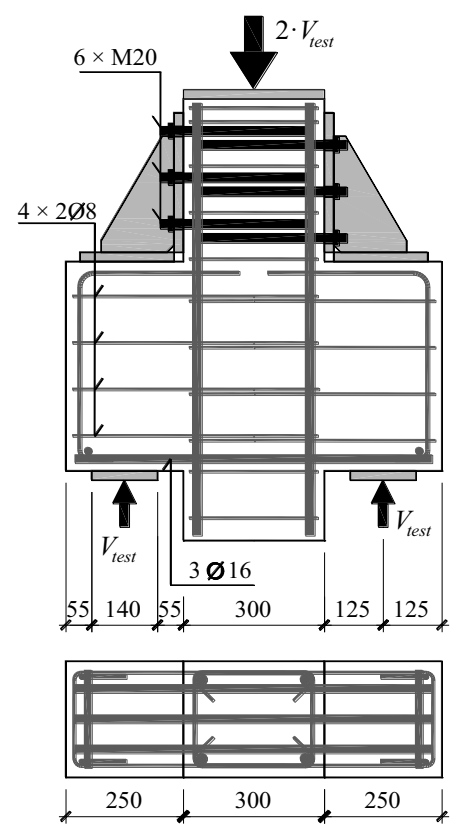

b)

Fig. 3 Reinforcement of tested elements: a) reference F- 0 b) strengthened F - I

The most important characteristics of reinforcement steel in the tested elements can be described: the main bars $\phi 16$ - yield strength $f_{y}=534,8 \mathrm{MPa}$, cross section area $\mathrm{A}_{\mathrm{s}}=2,01 \mathrm{~cm}^{2}$, the stirrups $\phi 8$ 
- $f_{y}=499,6 \mathrm{MPa}, \mathrm{A}_{\mathrm{s}}=0,45 \mathrm{~cm}^{2}$, the embedded threaded rods $-f_{y}=856,4 \mathrm{MPa}, \mathrm{A}_{\mathrm{s}}=2,28 \mathrm{~cm}^{2}$. In Fig. 5 stress - strain $\left(\sigma_{s}-\varepsilon_{s}\right)$ curves are shown.
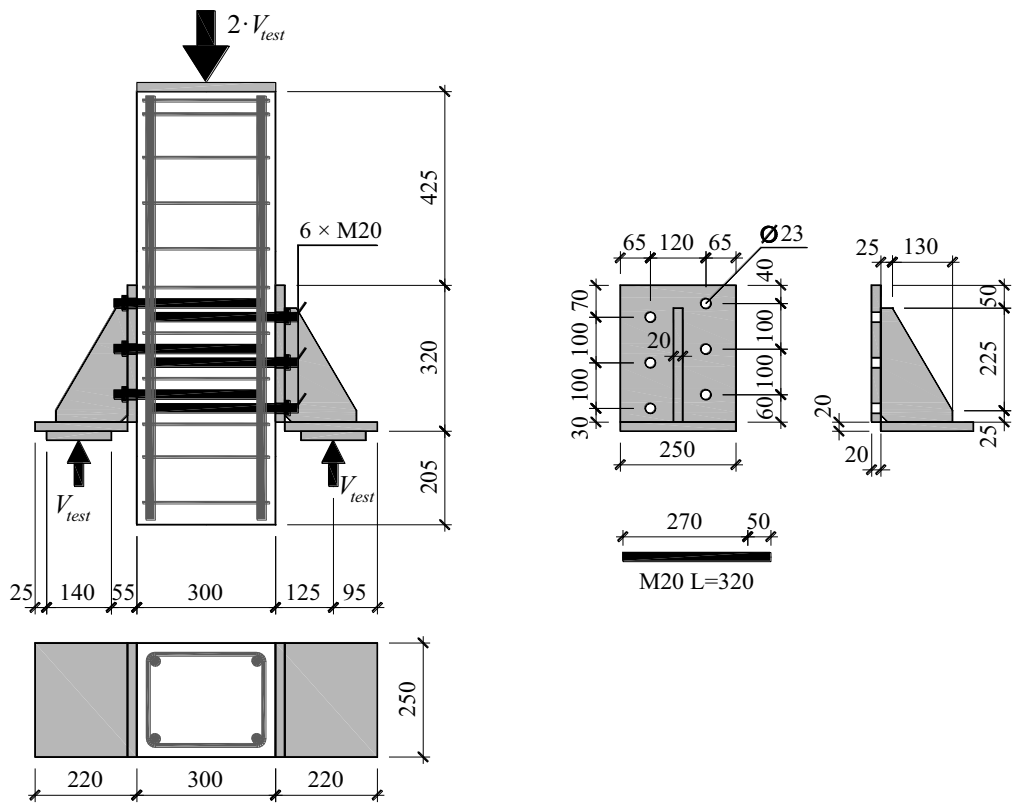

Fig. 4 View of column with embedded steel accessory F - II.

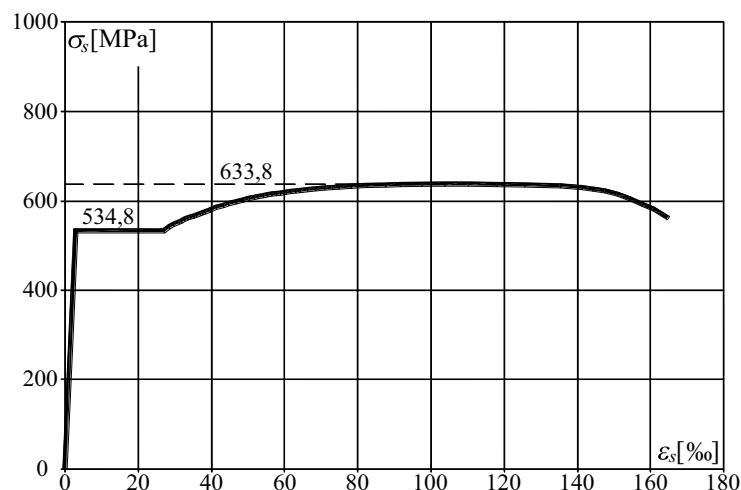

a)

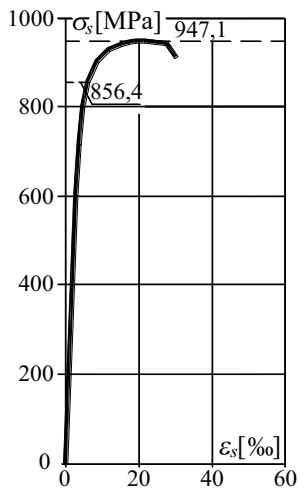

b)

Fig. 5 Stress - strain curves for steel: a) main reinforcement b) embedded rods.

Each of the elements was made of the same ready-mixed concrete delivered in one concrete mixer. Experimental research was carried after $58 \div 71$ days of concrete curing which guaranteed constant 
compressive strength. Average ultimate compressive stress in an uniaxial test was $f_{c}=35,2 \mathrm{MPa}$, splitting tensile strength was $f_{c t, s p}=3,47 \mathrm{MPa}$. For both values low coefficients of variation equal respectively about $3,0 \%$ and $6,5 \%$ were observed. In Table 1 more detail information is presented.

Table 1 Results of concrete specimens test - compressive strength, tensile strength (splitting), Young modulus, density.

\begin{tabular}{|c|c|c|c|c|}
\hline & $f_{c}$ & $f_{c t, s p}$ & $E_{c m}$ & $\rho$ \\
\cline { 2 - 5 } & $\mathrm{MPa}$ & $\mathrm{MPa}$ & $\mathrm{MPa}$ & $\mathrm{kg} / \mathrm{m}^{3}$ \\
\hline Average value & 35,2 & 3,47 & 26067 & 2250 \\
\hline Coefficient of variation & $2,84 \%$ & $6,58 \%$ & $5,93 \%$ & $0,68 \%$ \\
\hline Number of specimens & 18 & 15 & 15 & 36 \\
\hline
\end{tabular}

\section{EXPERIMENTAL RESULTS}

While increasing a load value some measurements were carried out. The strain gauges were used to check strain of the main reinforcement and the stirrups in the line of a column face. Additionally, the surface of the corbel was recorded by Digital Image Correlation System in order to obtain more data. A crack pattern was drawn after each loading step and crack width was measured.

In Figure 6 main reinforcement strain is presented. Behaviour of element F - I was very similar to reference corbel $\mathrm{F}-0$ up to strengthening. For load higher than $500 \mathrm{kN}$ significantly less increase of the strain was observed for the same difference of force for corbel $\mathrm{F}-\mathrm{I}$ than for $\mathrm{F}-0$. It means that stiffness of the strengthened element is noticeably higher than for the reference one. As a result,

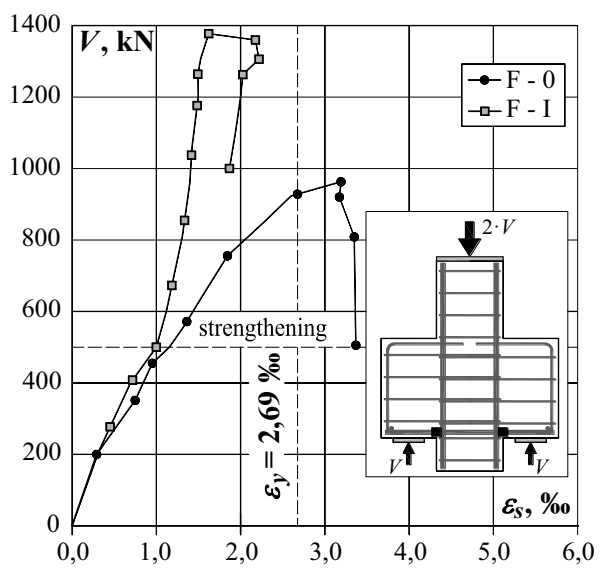

Fig. 6 Strain of main reinforcement. 
the main reinforcement in $\mathrm{F}-\mathrm{I}$ obtained lower values of strain than both yield strain and in $\mathrm{F}-0$ for higher value of load. The main reinforcement strain after failure did not increase.

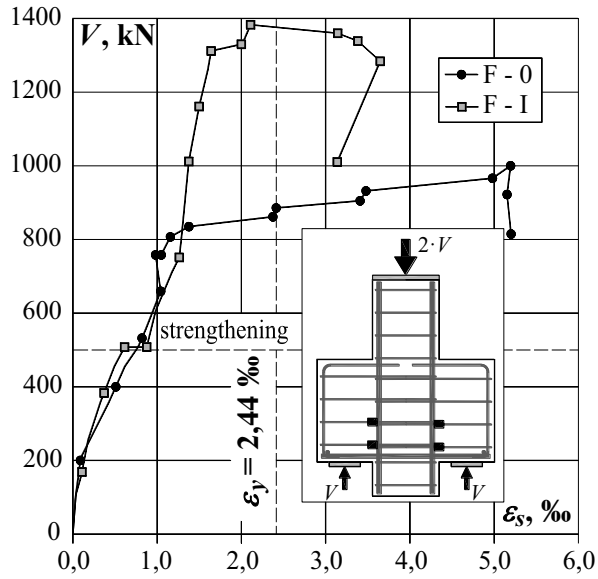

a)

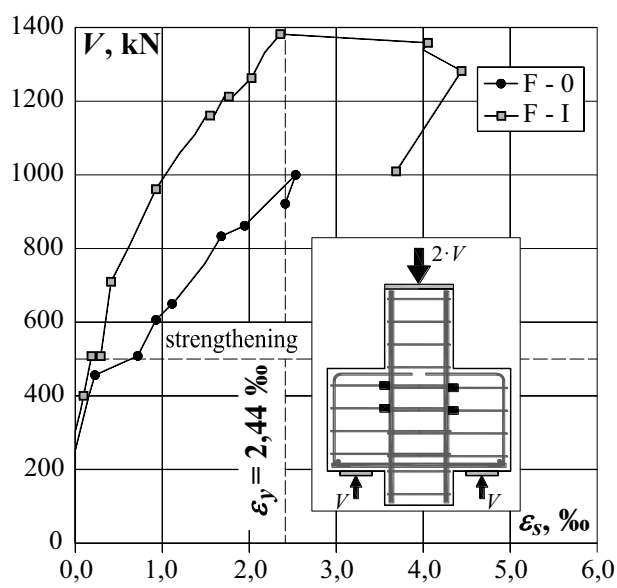

b)

Fig. 7 Strain of stirrups a) no. 1, 2 b) no. 3, 4 .

In Fig. 7 stirrups strain is presented. Stirrups located closer the main reinforcement (no. 1 and 2) obtained strain higher than yield strain for both F -0 and F - I (see Fig. 7a). Bar strain in F - 0 rapidly increased for load $0,8 V_{u l t}$. For similar value of force the main reinforcement obtained yield strain. For stirrups no. 1 and 2 in F - I linear increase of strain up to ultimate load was observed. Yield strain was obtained during the failure of the corbel. Behaviour of stirrups no. 3 and 4 is presented in Fig. 7b. It can be stated that strain for stirrups in F - 0 and F - I is similar (strain referring to ratio $\left.V / V_{u l t}\right)$. For both elements failure of and strain near yield strain of stirrups no. 3 and 4 were obtained at the same time.

In Fig. 8 strain of the steel accessories is presented. Values are similar for both 1 and 2 gauges for corbel F - I. In F - II significant differences between the gauges are observed for loads higher than $400 \mathrm{kN}$. The strain read by gauge no. 2 was several times bigger than for no. 1 .

For ultimate force compressive strain was about 1,2 \%o for F - I. Much higher strain was observed in element F - II, which is caused by lower depth value of the element carrying load (see Fig. 8 and 9).

In Fig. 10 comparison of the crack width located in tensioned corner is presented. Location of that crack is shown in Fig. 10. Crack width was very similar for both the elements before strengthening and a bit less for $\mathrm{F}$ - I after strengthening, the value stabilized for load higher than $800 \mathrm{kN}$. 


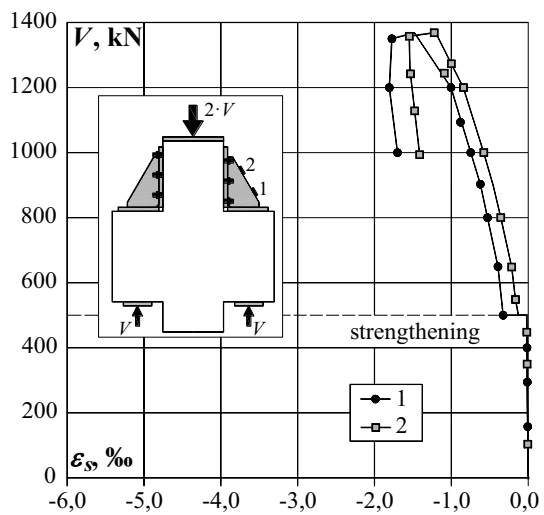

a)

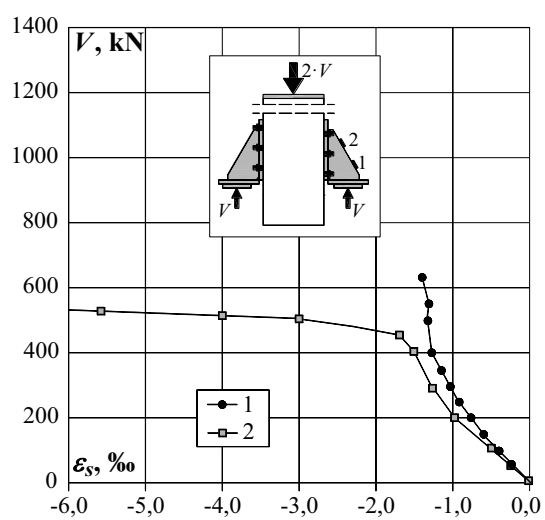

b)

Fig. 8 Strain on steel accessory surface a) F - I b) F - II

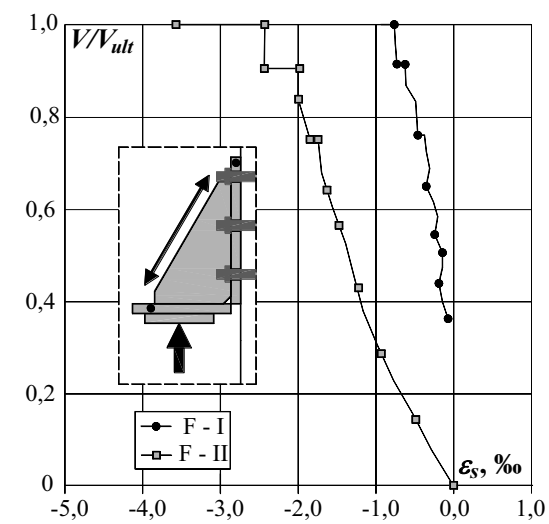

Fig. 9 Strain on steel accessory surface according to Aramis.

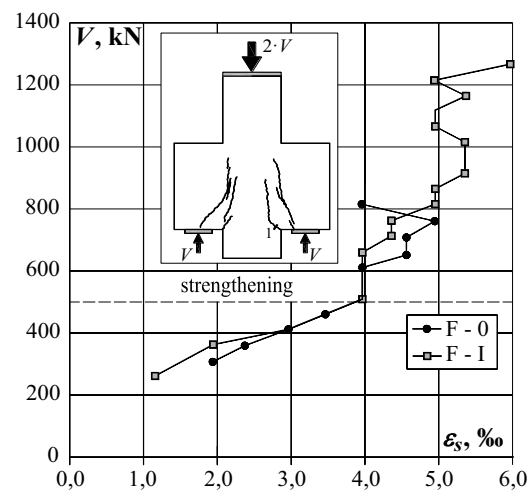

Fig. 10 Comparison of crack width for corbels. 


\section{FAILURE OF ELEMENTS}

Views of the elements after failure are presented in Fig. 11. Crack patterns of F- 0 and F - I are characteristic for shear failure described by Kriz and Raths [25]. It is a typical failure of corbels with low value of shear slenderness. Yield strain of the steel rib edge was locally reached in $\mathrm{F}-\mathrm{I}$ (Fig. 8 and 9).

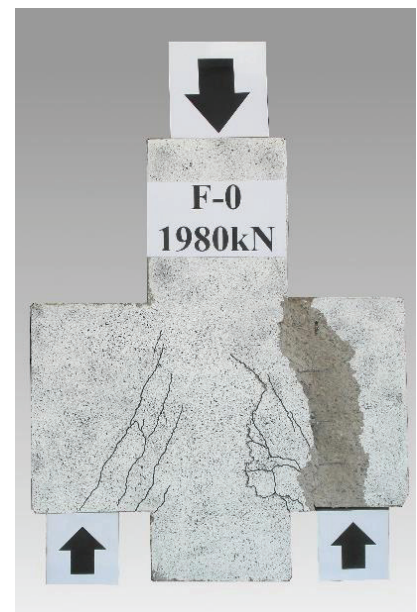

a)

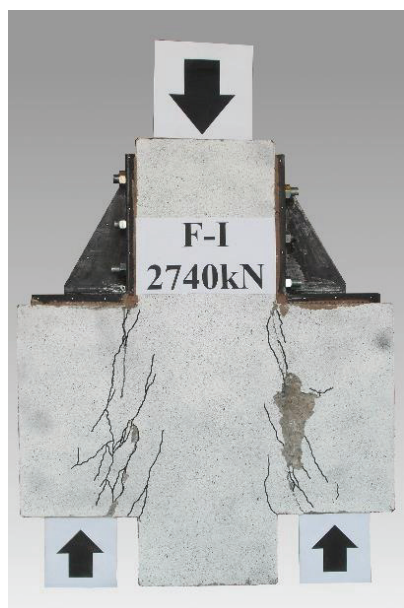

b)

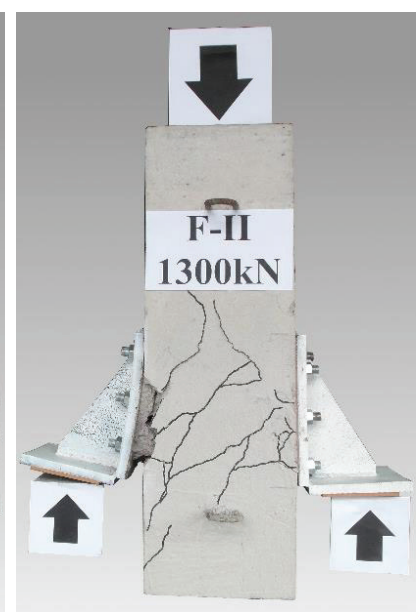

c)

Fig. 11 Elements after failure a) F - 0 b) F - I c) F - II.

In element F - II flexure of the accessory and as a result concrete failure were observed. In Fig. 12 the accessory after failure with bending angle is shown. The highest value of strain was obtained between the first and the second row of rods. The FEM calculations including bond anchor plasticity confirms the concentration of strain in the same area. A characteristic painted surface peeling of the rib is the proof that the significant value of strain occurred (see Fig. 12).

The most important observations are values of failure force for elements. Load carrying capacities were $990 \mathrm{kN} \mathrm{F}-$ 0, $1390 \mathrm{kN} \mathrm{F}$ - I while the steel accessory (F - II) obtained $650 \mathrm{kN}$ (value for each of the two corbels in the element). Using the steel accessory increased element capacity by $40 \%$ against reference corbel. $66 \%$ force of $\mathrm{F}-0$ was obtained for the steel accessories.

Table 2 Ultimate load obtain for corbels.

\begin{tabular}{|c|c|c|c|}
\hline Corbel & $\mathrm{F}-0$ & $\mathrm{~F}-\mathrm{I}$ & $\mathrm{F}-\mathrm{II}$ \\
\hline$V_{u l t}, \mathrm{kN}$ & 990 & 1390 & 650 \\
\hline
\end{tabular}




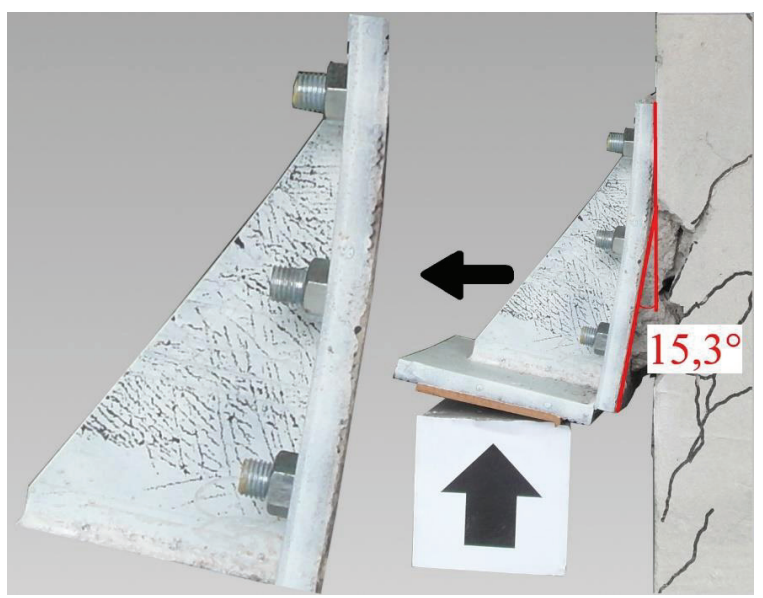

Fig. 12 Steel accessory after F - II failure.

\section{CONCLUSION}

The paper presents behavior of the three corbels. Load capacity of the bracket strengthened by the steel accessory mounted to cracked loaded corbel was significantly (by $40 \%$ ) higher than the reference one. The capacity of steel accessory mounted to concrete column was $66 \%$ of the reference corbel.

In the authors' opinion steel accessory capacity was decisive for F - II failure. The steel yielding of the rib was obtained and next, as a result, failure of the element started. Very important limitation of load capacity which has to be considered is resistance of embedded rods in concrete. A suitable size of a steel accessory as well as dimensions necessary for embedding sufficient number of rods should be considered at the designing stage. A significant increase in the capacity of the element tested in a natural scale is the reason why the presented method can be considered to use by engineers in practice. 


\section{REFERENCES}

1. S. Ahmad, A. Shah, A. Nawaz, K. Salimullah, "Shear Strengthening of Corbels with Carbon Fibre Reinforced Polymers (CFRP)", Materiales de Construcción, 2010;60:79-97.

2. M. Breveglieri, "Shear strengthening of RC beams using the Embedded Through-Section Technique", Università degli Studi di Ferrara; 2014.

3. M. Breveglieri, A. Aprile, J.A.O. Barros, "Embedded Through-Section shear strengthening technique using steel and CFRP bars in RC beams of different percentage of existing stirrups", Composite Structures, 2015;126:101-13.

4. M. Breveglieri, A. Aprile, J.A.O. Barros, "Shear strengthening of reinforced concrete beams strengthened using embedded through section steel bars", Engineering Structures, 2014.

5. M.M. Breveglieri, A. Aprile, J.A.O. Barros, "RC beams strengthened in shear using the Embedded Through-Section technique: Experimental results and analytical formulation", Composites Part B: Engineering, 2016;89:266-81.

6. G. Campione, L. La Mendola, M. Papia, "Flexural behaviour of concrete corbels containing steel fibers or wrapped with FRP sheets", Materials and Structures, 2005;38:617-25.

7. R.W. Corry, C.W. Dolan, "Strengthening and Repair of a Column Bracket Using a Carbon Fiber Reinforced Polymer (CFRP) Fabric", PCI Journal, 2001;46:54-63.

8. T.A. El-Maaddawy, E.-S.I. Sherif, "Response of Concrete Corbels Reinforced with Internal Steel Rebars and External Composite Sheets: Experimental Testing and Finite Element Modeling", Journal of Composites for Construction, 2014;18.

9. M.A. Elgwady, M. Rabie, M.T. Mostafa, "Strengthening of Corbels Using CFRP an Experimental Program", 2005. 10. EN-1992-1-1, "EN 1992-1-1: Eurocode 2: Design of Concrete Structures - Part 1: General rules and rules for buildings European Commitiee For Standardization", 2008.

11. M. Fernández Ruiz, A. Muttoni, J. Kunz, "Strengthening of Flat Slabs Against Punching Shear Using Post-Installed Shear Reinforcement", ACI Structural Journal, 2010;107:434-42.

12. I. Ivanova, "Mechanical behavior of short concrete corbels reinforced or repaired by bonding of composite materials (in French)", Université De Reims Champagne-Ardenne École, Université De Technologie Chimique Et De Métallurgie (Bulgarie); 2013.

13. Ł. Krawczyk, "Wzmacnianie krótkich wsporników żelbetowych zbrojeniem wklejanym", Politechnika Łódzka; 2017.

14. Ł. Krawczyk, M. Gołdyn, T. Urban, "O niedokładnościach systemów cyfrowej korelacji obrazu", Journal of Civil Engineering, Environment and Architecture, 2017;64:259-70.

15. Ł. Krawczyk, T. Urban, "Experimental research and modelling of corbel strengthened by steel accessory", In: fib Symposium Mastricht 2017. 2017. p. 1-8.

16. L.B. Kriz, C.H. Raths, "Connections in Precast Concrete Structures- Strength of Corbels", PCI Journal, 1965;10:1661.

17. J. Kunz, M. Fernández Ruiz, A. Muttoni, "Ehanced Safety With Post-Installed Shear Reinforcement", In: fib Symposium Tel-Aviv 2013. 2013. p. 155-8.

18. K. Nagrodzka-Godycka, "Wzmacnianie wsporników żelbetowych", Przegląd Budowlany, 1997;69:11-3.

19. K. Nagrodzka-Godycka, "Behavior of Corbels with External Prestressing Bars - Experimental Study", ACI Structural Journal, 1999;96:1033-9.

20. K. Nagrodzka-Godycka, "Badania bardzo krótkich wsporników żelbetowych", Inżynieria i Budownictwo, 2001;57:349-50.

21. K. Nagrodzka-Godycka, "Wsporniki żelbetowe: badania, teoria, projektowanie", Wydawnictwo Politechniki Gdańskiej; 2001.

22. T. Urban, Ł. Krawczyk, "Strengthening corbels using post-installed threaded rods", Structural Concrete, $2017 ; 18$.

23. T. Urban, "Badania belek żelbetowych wzmocnionych dwoma sposobami", Inżynieria i Budownictwo, 2002;58:106-9.

24. T. Urban, "Badania eksperymentalne stref ścinania wzmocnionych zbrojeniem wklejanym", In: XLII Konferencja Naukowa KILIW PAN i KN PZITB. Tom 4. 1996.

25. T. Urban, "Wzmacnianie konstrukcji żelbetowych metodami tradycyjnymi", PWN; 2015.

26. T. Urban, Ł. Krawczyk, M. Gołdyn, "Badania eksperymentalne wzmacniania bardzo krótkich wsporników żelbetowych", Journal of Civil Engineering, Environment and Architecture, 2016;63:297-306. 


\section{LIST OF FIGURES AND TABLES:}

Fig. 1. Rods anchoring accessory to column: a) view rods before embedded b) corbel after strengthening Rys. 1. Śruby mocujące akcesorium do słupa: a) widok śrub przed wklejeniem, b) wspornik po wzmocnieniu Fig. 2. View of testing element a) steel accessory b) rods surrounded by mortar after failure of element.

Rys. 2. Widok badanego elementu a) akcesorium stalowe, b) pręty wklejone otoczone żywicą po zniszczeniu elementu

Fig. 3 Reinforcement of tested elements: a) reference F -0 b) strengthened F - I

Rys. 3 Zbrojenie badanych wsporników a) referencyjnego F - 0 b) wzmocnionego F - I

Fig. 4 View of column with embedded steel accessory F - II.

Rys. 4 Widok słupa z wklejonym akcesorium F - II.

Fig. 5 Stress - strain curves for steel: a) main reinforcement b) embedded rods.

Fig. 5 Krzywe naprężenie - odkształcenie dla stali a) zbrojenie główne, b) pręty wklejone.

Fig. 6 Strain of main reinforcement.

Rys. 6 Odkształcenia zbrojenia głównego

Fig. 7 Strain of stirrups a) no. 1, 2 b) no. 3, 4 .

Rys. 7 Odkształcenia strzemion a) $\mathrm{nr} \mathrm{1,2} \mathrm{b)} \mathrm{nr} \mathrm{3,} 4$.

Fig. 8 Strain on steel accessory surface a) F - I b) F - II

Rys. 8 Odkształcenia na powierzchni akcesorium stalowego a) F - I b) F - II

Fig. 9 Strain on steel accessory surface according to Aramis.

Rys. 9 Odkształcenia na powierzchni akcesorium stalowego według Aramisa.

Fig. 10 Comparison of crack width for corbels.

Rys. 10 Porównanie szerokości rozwarcia rys.

Fig. 11 Elements after failure a) F - 0 b) F - I c) F - II.

Rys. 11 Elementy po zniszczeniu a) F - 0 b) F - I c) F - II.

Fig. 12 Steel accessory after F - II failure.

Rys. 12 Akcesorium stalowe po zniszczeniu F - II.

Table 1 Results of concrete specimens test - compressive strength, tensile strength (splitting), Young modulus, density.

Tablica 1 Wyniki badań próbek betonowych - wytrzymałość na ściskanie, wytrzymałość na rozciąganie przy rozłupywaniu, moduł sprężystości podłużnej, gęstość.

Table 2 Ultimate load obtain for corbels.

Tablica 2 Siły niszczące uzyskane dla wsporników. 


\section{WZMACNIANIE BARDZO KRÓTKIEGO WSPORNIKA ZA POMOCĄ STALOWEGO AKCESORIUM}

Slowa kluczowe: wsporniki, wzmacnianie, akcesorium stalowe, pręty wklejone, metoda wklejania zbrojenia

\section{PODSUMOWANIE:}

Problematyka wzmacniania wsporników żelbetowych była podejmowana przez różne ośrodki badawcze na świecie. Do elementów montowano dodatkowe zbrojenie stalowe bez przyczepności do betonu lub przyklejano taśmy bądź maty z włókien CFRP. Na podstawie przytoczonych prac można stwierdzić, że niszczenie modeli wzmocnionych CFRP przebiega gwałtownie, jest niesygnalizowane a nośność wsporników jest ograniczana przyczepnością taśm lub mat do betonu. Badano również wsporniki z wklejonymi prętami stalowymi. Kolejnym sposobem na wzmacnianie wsporników jest użycie stalowego akcesorium zamocowanego za pomocą prętów wklejonych do słupa.

Do badań prezentowanych w niniejszym artykule przygotowano trzy elementy. Dwa wsporniki wykonano jako elementy żelbetowe o wysokości $450 \mathrm{~mm}$, szerokości $250 \mathrm{~mm}$, stopniu zbrojenia podłużnego $\rho_{l} \approx 0,6 \%$ oraz smukłości $a_{c} / d \approx 0,3$. Oprócz zbrojenia głównego zastosowano w nim cztery dwucięte strzemiona wykonane z pręta $\phi 8$. Element F - I obciążono i utrzymując siłę zewnętrzną wzmocniono poprzez zamontowanie akcesorium stalowego za pomocą gwintowanych prętów wklejonych M20. Wspornik referencyjny (F - 0) zbadano bez zastosowania elementu wzmacniającego. Element F - II wykonano jako słupek, do którego zamocowano identyczne jak w F - I elementy stalowe. Elementy badano w pozycji obróconej obciążając je symetrycznie.

Najistotniejszą obserwacją są wartości sił niszczących poszczególne elementy. Nośność F - 0 wynosiła 990 kN, F - I była równa $1390 \mathrm{kN}$ podczas gdy dla samego akcesorium (wspornika stalowego F - II) uzyskano $650 \mathrm{kN}$. Użycie akcesorium stalowego pozwoliło podnieść nośność elementu F - I o 40 \% w odniesieniu do wspornika referencyjnego $\mathrm{F}-0$. Nośność wsporników stalowych (F - II) wynosiła $66 \%$ siły niszczącej F - 0 .

Sztywność wspornika wzmocnionego (F - I), po zamocowaniu elementu stalowego, była zauważalnie wyższa od referencyjnego $(\mathrm{F}-0)$. Zarysowanie elementów są charakterystyczne dla zniszczenia przez ścinanie. Jest to typowe zniszczenie wsporników o niskiej wartości smukłości ścinania. Zniszczenie wspornika F - II zostało zainicjowane przez uplastycznienie żebra, po którym nastąpiło niszczenie elementu (wyciąganie prętów). Bardzo istotnym ograniczeniem nośności takiego wzmocnienia jest nośność wklejenia prętów w beton.

Na podstawie przeprowadzonego eksperymentu można stwierdzić, że symetryczny wspornik obciążony siłą pionową może zostać wzmocniony za pomocą stalowego stołeczka (osiągnięto wzrost nośności o 40\%). Wykazano, że za pomocą wklejanych do słupa prętów można zainstalować stalowe akcesoria, które mogą spełniać zadanie wsporników stalowych. 